\title{
Persistent diarrhoea: clinical efficacy and nutrient absorption with a rice based diet
}

\author{
S K Roy, R Haider, M S Akbar, A N Alam, M Khatun, R Eeckels
}

\begin{abstract}
Twenty six infant boys, aged 4 to 18 months, suffering from persistent diarrhoea and 25 age matched healthy controls without diarrhoea were given a diet based on rice powder, egg white, glucose, and soya oil. The clinical efficacy of the diet was studied and a 72 hour metabolic balance study was done. Twenty one patients recovered from diarrhoea within seven days. Median coefficients of absorption of nutrients in persistent diarrhoea patients were $68.0 \%$ (range 28.0 to 92.0 ) for total energy, $60.0 \%$ (range 21.0 to 97.0 ) for fat, $53.0 \%$ (range -122.0 to 82.0 ) for nitrogen, and $81.0 \%$ (range 23.0 to 97.0 ) for carbohydrates. The corresponding values among the control subjects were $90.0 \%$ (range 76.0 to 99.0 ), $95.0 \%$ (range 71.0 to 99.0 ), $70.0 \%$ (range 10.0 to 95.0 ), and $93.0 \%$ (range 85.0 to 98.0 ) respectively. Absorption of all macronutrients in the control subjects was on average significantly higher than in the patients. Nutrient absorption is substantially reduced in persistent diarrhoea and a rice based diet is clinically effective in most patients.
\end{abstract}

Persistent diarrhoea is frequent in children from deprived communities. Its cause is still largely unknown. Though there is no general agreement, persistent diarrhoea has been defined as an episode of apparently acute diarrhoea that, however, lasts for more than 14 days. ${ }^{1}$ Intestinal pathogens are rarely isolated from the stools of patients with persistent diarrhoea. ${ }^{2}$ The management remains problematical, ${ }^{3}$ and very sophisticated and special procedures have been used. ${ }^{4}$ There are only a limited number of studies on malabsorption of nutrients in acute diarrhoea $^{5}$ due to specific enteropathogens ${ }^{6}$ and none in persistent diarrhoea. In persistent diarrhoea, malabsorption of nutrients has been attributed to loss of brush border enzymes, ${ }^{7}$
Patients and methods

About 70000 patients annually attend the International Centre for Diarrhoeal Disease Research, Bangladesh (ICDDR,B) treatment centre; about 300 of these patients have persistent diarrhoea. Twenty six boys, aged 4 to 18 months, who qualified for the study were selected consecutively. Inclusion criteria were: non-bloody diarrhoea lasting for more than 14 days and liquid or watery stools with a frequency of four per day or more. Exclusion criteria were: isolation of Vibrio cholerae, Salmonella spp, or Shigella spp from the stools, systemic infections, kwashiorkor, and exclusive breast feeding. The 25 healthy controls of comparable age were selected from the children who had visited ICDDR,B for diarrhoea at least four months earlier and had no history of diarrhoea within the previous two months. This study was approved by the ICDDR,B ethical review committee. Informed written consent was obtained from the parents of the subjects. On the day of admission, the patients were rehydrated, with an intravenous polyelectrolyte solution containing sodium $133 \mathrm{mmol} / \mathrm{l}$, potassium $13 \mathrm{mmol} / \mathrm{l}$, chloride $98 \mathrm{mmol} / \mathrm{l}$, and bicarbonate (as acetate) $48 \mathrm{mmol} / \mathrm{l}$.

\section{BASELINE INVESTIGATIONS}

The following data were collected: measurement of food and fluid intake, stool, urine, and vomit every eight hours. Blood electrolytes, white cell count, routine urine analysis, stool microscopic examination for Giardia lamblia and cryptosporidium were done on admission. Stools were cultured for $V$ cholerae, Shigella spp, Salmonella spp, enterotoxigenic Escherichia coli, and Campylobacter jejuni by standard microbiological techniques. For detection of rotavirus an enzyme linked immunoabsorbent assay (ELISA) method was used. Stool pH was measured with a $\mathrm{pH}$ meter and glucose was estimated by a glucose oxidase method. ${ }^{15}$ On admission body weight, length, and mid upper arm circumference were taken by a trained nutritionist. Subsequently, the children were weighed daily at the same hour (9-10 am). A metabolic balance (Ohaus) with a precision of $1 \mathrm{~g}$ was used to measure the body weight. Length was measured by a locally made length board with a precision of $1 \mathrm{~mm}$ and mid upper arm circumference by a TALC (Teaching Aid at Low Cost) tape with a precision of $2 \mathrm{~mm}$. Nutritional state was calculated as percent of the 50th centile National Center for Health Statistics standard. ${ }^{16}$ For estimation of intake of breast \footnotetext{
small intestinal bacterial overgrowth, ${ }^{8}$ derangement of bile acid metabolism, ${ }^{9}$ mucosal injury associated with cows' milk protein sensitive enteropathy, ${ }^{10}$ and severe protein energy malnutrition ${ }^{11}$ with reduced brush border and pancreatic enzymes. ${ }^{12} 13$ Symptomatic management of persistent diarrhoea with different diets has been partially successful. ${ }^{24}{ }^{14}$ Yet proper choice of the ingredients of a successful diet needs an assessment of intestinal absorption capacity. A clinical trial and a metabolic balance study was undertaken to test the effectiveness of a simple diet and to examine the importance of malabsorption in persistent diarrhoea.

Correspondence to: Dr S K Roy, Dhaka - 1000, Bang 128, Accepted 8 November 1989

Dhaka Shishu Hospital, Sher-E-Bangla Nagar, M S Akar
} 
Table 1 Composition of study diet

\begin{tabular}{lcc}
\hline & Weight $(\mathrm{g})$ & mmolll \\
\hline Rice powder & 30 & - \\
Egg white & 50 & - \\
Soya bean oil & 20 & - \\
Glucose & 25 & 139 \\
Potassium chloride & 1 & 17 \\
Sodium chloride & 1 & 5 \\
Magnesium chloride & 0.5 & 9 \\
Calcium chloride & 1 & \\
Water (ml) & 935 & \\
Cooked volume (ml) & 1000 & \\
Energy (MJ) & 1.67 & \\
Osmolality (mmol/kg) & 280 & \\
\hline
\end{tabular}

milk, the patients were weighed before and after each breast feeding.

\section{STUDY DIET}

A liquid diet was prepared with rice powder, egg white, soya oil, glucose, salt, and water. It contained $0.17 \mathrm{MJ} / 100 \mathrm{ml}$ with $8 \%$ energy from protein (table 1). The diet was prepared as follows. The ingredients were collected and measured as required with a balance. The whites of two duck eggs were separated, weighed, and then mixed with rice powder, glucose, and soya oil and taken in about a litre of water and boiled for about five minutes. The final volume was made up with additional water and then salts and minerals were added. The cost of the diet was US\$ 0.25 for one litre. Hourly feeds were given freely. Breast feeding on demand was encouraged. The diet was given for at least seven days. If there was evidence of clinical deterioration with increased diarrhoea a comminuted chicken based diet was given. Recovery was defined as a change of stool consistency from liquid to soft. Success with the study diet was defined as recovery within seven days.

\section{BALANCE STUDY}

The balance study was done as described by Molla et al. ${ }^{6}$ It was initiated 24 hours after patients and control children started taking the study diet. Charcoal was given as a marker at the start of the balance period and 72 hours later. Collection of stool and urine was done after the appearance of the first marker and until that of the second one. Five $\mathrm{ml}$ of acetic acid were put in the stool collecting pot to reduce bacterial growth and fermentation. After weighing the homogenised 72 hour stool samples, aliquots were analysed for total fat by Vande Kamer's method, ${ }^{17}$ nitrogen by the

Table 2 Median (range) daily average stool weight and stool frequency of the patients during the first five days on the study diet

\begin{tabular}{lll}
\hline Days & $\begin{array}{l}\text { Stool weight } \\
(\mathbf{g} / \mathbf{k g} / \text { day })\end{array}$ & $\begin{array}{l}\text { Stool frequency } \\
(\text { No/day })\end{array}$ \\
\hline 1 & $98(31-329)$ & $14(4-40)$ \\
2 & $86(11-255)$ & $11(2-24)$ \\
3 & $84(13-357)$ & $9(1-35)$ \\
4 & $71(3-310)$ & $8(1-29) \dagger$ \\
5 & $65(6-398)^{*}$ & $7(2-42)^{*}$ \\
\hline
\end{tabular}

${ }^{*} \mathrm{p}<0.002$ and $+\mathrm{p}<0.01$ when compared with day 1 (Wilcoxon's matched pair signed test).
micro-Kjeldahl method, ${ }^{18}$ and total energy by adiabatic bomb calorimetry (Gallenkamp); carbohydrate was calculated by subtracting energy for fat and nitrogen from the total energy. The coefficient of intestinal absorption was calculated as: [(Intake-loss)/intake] $\times 100$.

\section{STATISTICAL PROCEDURES}

After entering data in a microcomputer, they were analysed using SPSS/pc+ software. Significance was assumed at the probability level of $5 \%$. Only age, length, and mid upper arm circumference were normally distributed. Therefore the Mann-Whitney $U$ test was used for comparison between groups. Wilcoxon's matched pair signed test was applied when subjects were used as their own controls.

\section{Results}

All 26 study children had liquid stools on admission. A total of six stool pathogens were isolated from stools of four patients. Campylobacter $(\mathrm{n}=1)$, enterotoxigenic $E$ coli $(\mathrm{n}=3)$, and rotavirus $(n=2)$. Seven days after the start of the diet, $21(81 \%)$ of the children had soft stools and were considered as having recovered. Nine of these patients (43\%) had already achieved recovery after three days. The remaining five children (19\%) failed to recover within seven days and were given a diet based on comminuted chicken. Their daily stool weights and frequencies are given in table 2 . Table 3 compares the main characteristics of the five children in whom treatment failed with those of the children who recovered. There were no differences in age, anthropometric indices, or duration of diarrhoea before admission. The median stool weights on days 1 and 5 were much higher in the children who failed to recover, however $(p<0.01$ and $p<0.002$ respectively), and so were the median coefficients of absorption for total energy $(p<0.001)$. All five who failed to recover were breast fed. Two of them developed bronchopneumonia and one developed urinary tract infection; all three responded well to antibiotics. All five recovered from their prolonged diarrhoea after a period ranging from nine to 39 days.

\section{BALANCE STUDY}

The general characteristics of patients and controls are given in table 4. Nutritional state of the controls was significantly better. Table 5 compares the dietary intake of patients and controls. The average total energy $(\mathrm{MJ} / \mathrm{kg} /$ day) and nutrient intakes $(\mathrm{g} / \mathrm{kg} / \mathrm{day})$ from the study diet were comparable between the groups but there was a significantly higher intake of breast milk among the patients. The balance, that is, intake-loss of energy and nutrients, however, indicated no significant differences between the two groups except for fat (table 6). More control children than patients were weaned, but the difference was not significant. Among the patients, malabsorption was most prominent for nitrogen and least so for carbohydrate (table 7), but some patients had coefficients of absorption 
Table 3 Main features of the five children who did not improve on rice based diet and those who recovered

\begin{tabular}{|c|c|c|c|c|c|c|}
\hline & Case 1 & Case 2 & Case 3 & Case 4 & Case 5 & $\begin{array}{l}\text { Median (range) for } \\
\text { children who recovered }\end{array}$ \\
\hline $\begin{array}{l}\text { Age (months) } \\
\text { Weight for age }\end{array}$ & 11 & 7 & 8 & 8 & 9 & $8(5-17)$ \\
\hline $\begin{array}{l}\text { (\% median NCHS) } \\
\text { Weight for height }\end{array}$ & 58 & 90 & 69 & 64 & 48 & $67(49-85)$ \\
\hline $\begin{array}{l}\text { (\% median NCHS) } \\
\text { Duration of diarrhoea }\end{array}$ & 75 & 90 & 79 & 79 & 65 & $82(66-90)$ \\
\hline $\begin{array}{l}\text { betore admission } \\
\text { (days) } \\
\text { Stool weight } \\
\text { (g/kg/day): }\end{array}$ & 15 & 26 & 25 & 45 & 20 & $17(14-60)$ \\
\hline $\begin{array}{l}\text { Day } 1 \\
\text { Day } 5 \\
\text { Time taken for }\end{array}$ & $\begin{array}{l}237 \\
240\end{array}$ & $\begin{array}{r}55 \\
398\end{array}$ & $\begin{array}{l}266 \\
217\end{array}$ & $\begin{array}{l}150 \\
123\end{array}$ & $\begin{array}{l}330 \\
204\end{array}$ & $\begin{array}{l}92(31-203) \\
33(6-135)\end{array}$ \\
\hline $\begin{array}{l}\text { recovery (days) } \\
\text { Energy intake from } \\
\text { breast milk }\end{array}$ & 22 & 9 & 11 & 39 & 15 & $4(2-7)$ \\
\hline $\begin{array}{l}\text { (M J/kg/day) } \\
\text { Coefficient of } \\
\text { absorption: }\end{array}$ & $0 \cdot 17$ & $0 \cdot 18$ & $0 \cdot 27$ & $0 \cdot 18$ & $0 \cdot 20$ & $0.15(0-0.24)$ \\
\hline $\begin{array}{l}\text { Nitrogen } \\
\text { Fat } \\
\text { Carbohydrate }\end{array}$ & $\begin{array}{r}-10 \cdot 0 \\
26 \cdot 0 \\
94 \cdot 0\end{array}$ & $\begin{array}{l}52 \cdot 0 \\
71 \cdot 0 \\
55 \cdot 0\end{array}$ & $\begin{array}{l}23 \cdot 0 \\
38 \cdot 0 \\
23 \cdot 0\end{array}$ & $\begin{array}{r}3 \cdot 0 \\
37 \cdot 0 \\
73 \cdot 0\end{array}$ & $\begin{array}{l}13 \cdot 0 \\
43 \cdot 0 \\
32 \cdot 0\end{array}$ & $\begin{array}{l}59(-122-82) \\
61(21-97) \\
85(35-97)\end{array}$ \\
\hline Complications & $\underset{\text { metro }}{\mathrm{SXT}}$ & - & $\begin{array}{l}\text { Urinary tract } \\
\text { infection } \\
\text { SXT, } \\
\text { gentamicin }\end{array}$ & $\begin{array}{l}\text { Lower respiratory } \\
\text { tract infection, } \\
\text { oedema } \\
\text { Ampicillin, } \\
\text { gentamicin }\end{array}$ & $\begin{array}{l}\text { Lower respiratory } \\
\text { tract infection, } \\
\text { sepsis, oedema } \\
\text { SXT, ampicillin, } \\
\text { gentamicin }\end{array}$ & \\
\hline
\end{tabular}

NCHS, National Center for Health Statistics.

SXT, Sulphamethoxazole-trimethoprim.

Table 4 Comparison of general characteristics between children with persistent diarrhoea and their controls. Results are median (range)

\begin{tabular}{llll}
\hline & $\begin{array}{l}\text { Patients } \\
(n=26)\end{array}$ & $\begin{array}{l}\text { Controls } \\
(n=25)\end{array}$ & $p$ Value $^{*}$ \\
\hline $\begin{array}{l}\text { Age (months) } \\
\text { Weight (kg) }\end{array}$ & $\begin{array}{c}8.5(5-17) \\
6(4 \cdot 3-8.4)\end{array}$ & $\begin{array}{c}10(5-18) \\
8(6.7-11 \cdot 7)\end{array}$ & $\begin{array}{l}0.14 \\
0.001\end{array}$ \\
$\begin{array}{l}\text { Length (cm) } \\
\text { Weight for age } \\
(\% \text { median }\end{array}$ & $66.6(56.0-75 \cdot 0)$ & $70.5(60.5-79.5)$ & 0.002 \\
$\begin{array}{l}\text { NCHS) } \\
\text { Weight for length } \\
\text { (\% median }\end{array}$ & $86.7(47-90)$ & $84.7(68-109)$ & 0.001 \\
$\begin{array}{l}\text { NCHS) } \\
\text { Mid upper arm } \\
\text { circumference } \\
(\mathrm{cm})\end{array}$ & $80.8(64-108)$ & $98.6(81-117)$ & 0.001 \\
\hline
\end{tabular}

${ }^{*}$ Mann-Whitney U test.

NCHS, National Center for Health Statistics.

Table 5 Comparison of nutrient intake between children with persistent diarrhoea and their controls. Results are median (range)

\begin{tabular}{|c|c|c|c|}
\hline & $\begin{array}{l}\text { Patients } \\
(n=26)\end{array}$ & $\begin{array}{l}\text { Controls } \\
(n=25)\end{array}$ & p Value ${ }^{*}$ \\
\hline $\begin{array}{l}\text { Energy total } \\
\text { (kcal/kg/day) } \\
\text { Energy from diet } \\
\text { alone } \\
\text { Energy from } \\
\text { breast milk } \\
(\mathbf{M J} / \mathbf{k g} / \text { day): } \\
\text { All children } \\
\text { Breast fed } \\
\text { children only } \\
\begin{array}{c}\text { Nitrogen } \\
(\mathbf{g} / \mathbf{k g} / \text { day })\end{array} \\
\text { Fat }(\mathbf{g} / \mathbf{k g} / \text { day }) \\
\text { Carbohydrate } \\
\text { (g/kg/day) }\end{array}$ & $\begin{array}{c}0 \cdot 18 \\
(0-0 \cdot 27) \\
0 \cdot 18 \\
(0 \cdot 01-0 \cdot 27) \\
(n=22) \\
0 \cdot 33 \\
(\cdot 22-\cdot 54) \\
4 \cdot 9 \\
(3-7 \cdot 9) \\
10 \cdot 5 \\
(5 \cdot 5-17 \cdot 5)\end{array}$ & 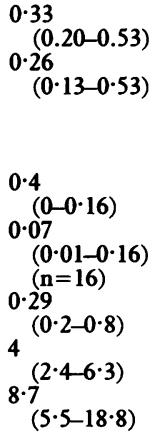 & $\begin{array}{l}0.0001 \\
0.01 \dagger \\
0.0014 \dagger \\
0.005 \uparrow\end{array}$ \\
\hline
\end{tabular}

${ }^{*}$ Mann-Whitney U test.

†Intake from study diet was not different.

comparable with those of the control subjects. In the controls, median coefficient of absorption of nitrogen was only $70 \%$; it was very low in two patients: $10 \%$ and $37 \%$, respectively. While the coefficients of energy and nutrients absorption
Table 6 Comparison of energy and nutrient balances between patients and controls. Results are median (range)

\begin{tabular}{|c|c|c|c|}
\hline & $\begin{array}{l}\text { Patients } \\
(n=26)\end{array}$ & $\begin{array}{l}\text { Controls } \\
(n=25)\end{array}$ & p Value \\
\hline $\begin{array}{c}\text { Energy balance } \\
(\mathrm{MJ} / \mathbf{k g} / \text { day })\end{array}$ & $\begin{array}{l}0.23 \\
(0.08-0.54)\end{array}$ & $\begin{array}{l}0.29 \\
\quad(0.18-0.50)\end{array}$ & 0.37 \\
\hline $\begin{array}{l}\text { Fat balance } \\
(\mathrm{g} / \mathbf{k g} / \text { day })\end{array}$ & 2.9 & $3 \cdot 7(2 \cdot 3-6 \cdot 1)$ & $0.03^{*}$ \\
\hline $\begin{array}{l}\text { Nitrogen balance } \\
\text { (g/kg/day) } \\
\text { Carbohydrate }\end{array}$ & $\stackrel{0.17}{(-0.3-0.38)}$ & $\begin{array}{l}0.19 \\
\quad(.03-0.42)\end{array}$ & $0 \cdot 30$ \\
\hline $\begin{array}{l}\text { balance } \\
\text { (g/kg/day) }\end{array}$ & $\begin{array}{l}8 \cdot 0 \\
(3 \cdot 0-17 \cdot 0)\end{array}$ & $\begin{array}{l}7 \cdot 7 \\
\quad(5 \cdot 1-17 \cdot 7)\end{array}$ & $0 \cdot 88$ \\
\hline $\begin{array}{l}\text { Intake of } \\
\text { dietary energy } \\
(\mathrm{MJ} / \mathrm{kg} / \text { day })\end{array}$ & $\begin{array}{l}0 \cdot 28 \\
\quad(0 \cdot 15-0 \cdot 45)\end{array}$ & $\underset{(0.13-0.53)}{0.26}$ & 0.67 \\
\hline $\begin{array}{l}\text { Non-breast } \\
\text { fed/total } \\
\text { children }\end{array}$ & $4 / 26$ & $9 / 25$ & $0.30 \dagger$ \\
\hline $\begin{array}{l}\text { No of feeds at the } \\
\text { breast/day } \neq\end{array}$ & $7(3-12)$ & $4(2-9)$ & $0.05^{*}$ \\
\hline
\end{tabular}

"Mann-Whitney $U$ test; $\uparrow \chi^{2}$ test.
$\ddagger$ Mean of three consecutive days during balance period.

Table 7 Comparison of the coefficients of absorption (\%) between patients and controls. Results are median (range)

\begin{tabular}{llll}
\hline Macronutrients & $\begin{array}{l}\text { Patients } \\
(n=26)\end{array}$ & $\begin{array}{l}\text { Controls } \\
(n=25)\end{array}$ & $p$ Value $^{*}$ \\
\hline Total energy & $68(28-92)$ & $90(76-99)$ & 0.001 \\
Nitrogen & $53(-122-82)$ & $70(10-95)$ & 0.001 \\
Fat & $60(21-97)$ & $95(71-99)$ & 0.001 \\
Carbohydrate & $81(23-98)$ & $93(85-98)$ & 0.001
\end{tabular}

${ }^{*}$ Mann-Whitney U test.

overlapped between the two groups, the median values were significantly different.

\section{Discussion}

In rural Bangladesh persistent diarrhoea, especially when associated with malnutrition, is considered as one of the most important causes of death in 1 to 4 year old children (V Fauveau, $M$ Yunus, $\mathrm{K}$ Zaman, et al, unpublished observations). Despite the severity of the disease and absence of definite outlines for management, most of our patients have been successfully treated with a simple rice based diet. The 
patients were severely ill, most of them were malnourished, and they had prolonged diarrhoea with high purging rates and gross malabsorption. Whether malnutrition was a cause or effect of persistent diarrhoea is not clear. Despite the high median purging rate $(98$ $\mathrm{g} / \mathrm{kg} /$ day) during the first 24 hours of admission, only half of the patients needed intravenous rehydration. This was consistent with the rapid response to the diet. The rapid recovery of 21 out of 26 patients compares well with the recovery of only three children out of 26 with a usual milk based diet reported previously, ${ }^{2}$ the more so because the diet is an inexpensive one and easily made locally. However, the present study did not address specific issues like comparisons with established treatment regimens, including use of intravenous fluids, and cost comparison. Both average stool weight and frequency diminished considerably and quickly during the first five days on the study diet. In the five children who did not improve with the study diet, stool weights increased and stool frequency remained high, and three among them had signs of systemic infection. It is not known to what extent the infections were responsible for the prolongation of the illness. These patients were not more malnourished than the other patients; clearly malnutrition was not correlated with treatment failure. The therapeutic diet had a low energy density $(0.17 \mathrm{MJ} / 100 \mathrm{ml})$ and the children were not used to its taste. The low energy density of the diet was due to its composition, which was about the half strength of a previously used diet with a success in about $50 \%$ of patients. ${ }^{2}$ This might explain the low average energy intake in both groups. Most of the patients were breast fed; this is the normal practice in this community. The intake of breast milk in our patients was of similar magnitude to that reported in children with acute diarrhoea. ${ }^{19} 20 \mathrm{~A}$ recent study in this country has shown that breast feeding reduces mortality among malnourished children. The much higher intake of breast milk by the patients is striking. The patients suckled more frequently than the controls. It is the higher volume of breast milk that led to a significantly higher median energy intake in the patients than in the control children. Yet the higher intake was offset by severe malabsorption and the energy balance in patients and controls was similar. Patients had on average severe malabsorption of energy, nitrogen, and fat. The absorption of carbohydrate was relatively higher, which might explain the success of our diet. Yet some of our patients had a normal coefficient of absorption while some of the control children cannot be considered as having a normal intestinal absorption. The latter has been found in another study from this country. ${ }^{21}$ As shown in acute diarrhoea, the carbohydrate absorption was higher than that of nitrogen and fat. ${ }^{6}$ Despite a low average absorption and energy balance the response to the diet was highly satisfactory. After the first week of treatment, the patients who improved were put on a diet with an energy density of $0.33 \mathrm{MJ} / 100$ $\mathrm{ml}$. They showed a rapid weight gain whereas during the first week of treatment their weight remained constant or decreased. The gross malabsorption in most cases of prolonged diarrhoea might explain the association of this disease with malnutrition and its high fatality rate. The diet we have used seems to be of real value as any moderately well equipped hospital should be able to prepare it, and it could be prepared at home. The search for a still more simple diet and for ways to prevent persistent diarrhoea must be continued.

ICDDR,B is supported by the countries and agencies which share its concern about the impact of diarrhoeal diseases on the developing world. We thank Ms N Majid for preparation of the study diet, Mr S Rahaman and Ms F Jahan for biochemica analysis, and Mrs A Begum, Mrs E Islam, Mrs J Sultanemical Mrs S Is, and Mrs A Begum, Mrs E Islam, Mrs J Sultana, and Mrs S Islam for contacting the parents of the control children. We are grateful for the kind help of Dr D Mahalanabis. We
thank Ms KE Islam, Mr MMR Ali, and Mr M Khan for secrethank Ms $\mathrm{K}$.

1 World Health Organisation. Persistent diarrhoea in children in developing countries. Report of a WHO meeting. Diarrhoeal developing countries. Report of a WHO meeting. Diarrhoeal
diseases control programme. Geneva: WHO, 1988. (CDD.1988.27.)

2 Roy SK, Alam AN, Majid N, Khan AM, Hamadani J, Shome GP. Persistent diarrhea: a preliminary report on clinical features and dietary therapy in Bangladeshi children. F Trop Pediatr 1989;35:55-9.

3 Avery GB, Villavicencio O, Lilly JR, Randolph JG. Intractable diarrhea in early infancy. Pediatrics 1968;41:712-22.

4 Larcher VF, Shepherd R, Francis DEM, Harries JT. Protracted diarrhoea in infancy: analysis of 82 cases with particular reference to diagnosis and management. Arch Dis Child 1977;52:597-605.

5 Chung AW. Effect of oral feeding at different levels on absorption of foodstuffs in infantile diarrhea. 7 Pediatr 1948;33:1-13.

6 Molla A, Molla AM, Rahim A, Sarker SA, Mozaffar Z, Rahaman M. Intake and absorption of nutrients in children with cholera and rotavirus infection during acute diarrhoea with cholera and rotavirus infection during acute diarrho

7 Rossi TM, Labenthal E, Nord KA, Fazili RR. Extent and duration of small intestinal mucosal injury in intractable duration of small intestinal mucosal injury in
diarrhea of infancy. Pediatrics 1980;66:730-5.

8 Gracey M, Burke V, Anderson CM. Association of monoGracey M, Burke V, Anderson CM. Association of mono-
sacharride malabsorption with abnormal intestinal flora. Lancet 1982;ii:384.

9 Balisteri WF. Bile acid induced intestinal dysfunction: implications to protracted infantile diarrhoea and malnutrition. In: Lebenthal E, ed. Chronic diarrhea in children. New York: Raven Press; 1984:347-64.

10 Iyngkaran N, Robinson MJ, Sumithran E, Lam SK, Puthucheary SD, Yadav M. Cows' milk protein sensitive enteropathy: an important factor in prolonging diarrhoea in acute infective enteritis in early infancy. Arch Dis Child 1978;53:150-3.

11 Chandra RK, Pawa RR, Ghai OP. Sugar intolerance in malnourished infants and children. $B r$ Med 7 1968;iv: 611-3

12 Jain MK, Bhui PS, Mehta NJ, Tasker SP, Sane SY, Mehta AP. Pancreatic function in malnourished children. In: Walker-Smith JA, McNeish AS, eds. Diarrhoea and malnutrition in childhood. London: Butterworths, 1986:142-6.

13 Mehta AP, Doiphode SH, Dhar AP, Jain MK. Bacterial overgrowth in the small intestine in malnourished children. In: Walker-Smith JA, McNeish AS, eds. Diarrhoea and malnutrition in childhood. London: Butterworths, 1986: 43-9.

14 Bhave SA, Pandit AN, Agarkhedkar SR. Protracted diarrhoea and its management. Indian $\mathcal{f}$ Pediatr 1983;20:173-8.

15 Trinder P. Glucose oxidase method. Ann Clin Biochem 1969;6:24.

16 National Center for Health Statistics. Growth charts United States. Rockville Pike, MD: Public Health Service, Health Resources Administration, 1976. (HRA 76-1129,25,3.)

17 Vande Kamer JH, Ten Bokkel Huiniuk H, Weyers HA. Rapid method of determination of fat in feces. 7 Biol Chem Rapid method of

18 Henry RJ. Clinical chemistry principles and technics. New York: Harper and Row, 1964.

19 Hoyle B, Yunus M, Chen LC. Breast-feeding and food intake among children with acute diarrheal disease. Am $\mathcal{F}$ Clin Nutr 1980;33:2365-71.

20 Sarker SA, Molla AM, Rahaman MM. Impact of supplementary food on intake of breast milk in diarrhoea. Lancet 1983;ii:1349-51.

21 Brown KH, Khatun M, Ahmed MG. Relationship of the xylose absorption status of children in Bangladesh to their absorption of macronutrients from local diets. Am $\mathcal{F}$ Clin Nutr 1981;34:1540-7. 